\title{
Competitive Adsorption of Metal Ions on Peanut Testa (Arachis hypogaea L.) Extract Using Cation Exchange Resins
}

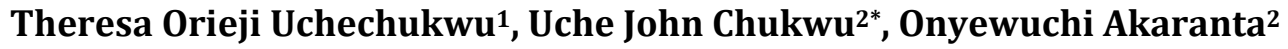 \\ ${ }^{1}$ Department of Chemistry, Biochemistry and Molecular Biology, Alexander Ekwueme Federal University, Ndufu Alike, Ikwo, \\ Abakaliki, Nigeria \\ ${ }^{2}$ Department of Pure and Industrial Chemistry, Faculty of Science, University of Port Harcourt, Port Harcourt, Nigeria \\ Email: *Lydiuche@gmail.com
}

How to cite this paper: Uchechukwu, T.O., Chukwu, U.J. and Akaranta, O. (2021) Competitive Adsorption of Metal Ions on Peanut Testa (Arachis hypogaea L.) Extract Using Cation Exchange Resins. Open Access Library Journal, 8: e7575.

https://doi.org/10.4236/oalib.1107575

Received: May 24, 2021

Accepted: December 13, 2021

Published: December 16, 2021

Copyright ( $) 2021$ by author(s) and Open Access Library Inc.

This work is licensed under the Creative Commons Attribution International License (CC BY 4.0).

http://creativecommons.org/licenses/by/4.0/

\section{(c) (i) Open Access}

\begin{abstract}
Competitive adsorption of $\mathrm{Fe}^{2+}, \mathrm{Ni}^{2+}, \mathrm{Pb}^{2+}, \mathrm{Cu}^{2+}$ and $\mathrm{Zn}^{2+}$ in a multi-element solution was compared with the adsorption of the same in individual element solutions using cation exchange resins developed from modified peanut testa extract (PTE) as adsorbents. Modified PTE-polyphenols cation exchangers were prepared by first crosslinking with phosphorus oxychloride $\left(\mathrm{POCl}_{3}\right)$ before functionalizing with chlorosulphonic acid (CSA). In another instance, PTE-polyphenols was only sulphonated using CSA. The produced resins were characterized by Fourier Transform Infrared (FTIR) spectroscopy, cation exchange capacity (CEC) and other properties. In addition to the FTIR absorption bands found in the 3400,2900 and $1600 \mathrm{~cm}^{-1}$ regions of the electromagnetic spectrum showing the presence of $-\mathrm{OH},-\mathrm{CH}_{2}$ and $-\mathrm{CH}$ groups in the starting materials, which were also present in the spectra of the products, new bands due to $-\mathrm{C}-\mathrm{O}-\mathrm{P}=\mathrm{O},-\mathrm{P}=\mathrm{O}$ and $\mathrm{R}-\mathrm{O}-\mathrm{P}-\mathrm{OH}$ stretching were observed at 1350, 1325, 1246 and $997 \mathrm{~cm}^{-1}$. Stretch bands due to -P-O-C- of aromatics, $\mathrm{O}=\mathrm{S}=\mathrm{O}$ and $\mathrm{SO}_{3} \mathrm{H}$ groups respectively created by phosphorylated, sulphonated and phosphosulphonated PTE were also found at 1278, 1190 and 1112 $\mathrm{cm}^{-1}$. The results showed that the CEC of Crosslinked-PPTE increased significantly from $6.7167 \mathrm{meq} / \mathrm{g}$ to $9.5267 \mathrm{meq} / \mathrm{g}$ after functionalization. The effect of the presence of a metal ion in the solution on the adsorption of another by the developed resins and a commercial ion exchange resin, Biorex 70 was investigated in terms of the amount of metal ions removed from the solutions.
\end{abstract}

\section{Subject Areas}

Inorganic Chemistry 


\section{Keywords}

Industry Wastewater, Peanut Testa Extract Polyphenols, Cation Exchange

Resins, Heavy Metals, Adsorption

\section{Introduction}

Industry wastewater and effluents are commonly contaminated with a variety of heavy metal ions rather than a single one. Heavy metals, like all poisonous substances are known to interfere with biological activities. Reference [1] listed taunted growth, reproductive impairment, cancer and mortality among the effects of heavy metal pollution in man. Additionally, organ damage and endangered life were equally reported [2]. Reference [3] explained that surplus Fe will deposit in the body organs and synthesize non-transferring-bound Fe. Lethargic protein metabolism and associated sterility in mammalian males are signs of the toxicity of $\mathrm{Zn}$ [4]. While partial blindness and imperfect hormonal activities are minor symptoms of $\mathrm{Pb}$ poisoning, undeveloped grey matter and consequential low acumen are indications of $\mathrm{Pb}$ build-up in humans [5]. Reference [6] reported carcinogenicity of $\mathrm{Ni}$ compounds to animals when in excess. This triggers hypoglycemia, nausea, headache and respiratory diseases [7]. Excess $\mathrm{Cu}$ manifests as diarrhea and dehydration, anaemia and paralysis amid other illnesses in vertebrates and distress benthos through organ damage and ultimate cessation of the animal's life [8] [9].

Other than reported oxidative stress in affected plants, [10] enumerated sedentary nutrients uptake and stumpy growth, chlorosis, low fruit yield, metabolic syndromes and nitrogen fixing disability in legumes as signs of heavy metals contamination in plants. The UNEP Joint Report (2010) [11] linked the reported annual 1.8 million infantile deaths from waterborne diseases to heavy metal polluted industry wastewater and effluents discharged into the world's waterways [12]. Corroborating, H. R. H. Prince Willem-Alexander of The Netherlands connected poor human health, declining agricultural yield and insignificant socioeconomic growth to indiscriminate discharge of wastewater into water courses and underscored its militating role against the advocacy for hygiene practice and ecosystem sustainability [13].

The above narrative shows the need to identify pollutant heavy metal ions in wastewater and remove them before releasing into the environment to avoid their build-up beyond the WHO permissible limits for industry discharges. The initiatives and fiscal commitments to good health have awakened the consciousness and stimulated interest and effort towards the purification of heavy metal polluted water. Moreover, the advocacy in developed countries for reduced presence of metal ions in water has generated support for the development of feasible ways to remedy heavy metal contaminated water and industry effluents and prompted stringent guidelines for their discharge into the environment [14] [15]. 
Citing the activism of global institutions to the objectives, [14] [16] highlighted the synergy between contemporary researchers on the development of safe, economical as well as practical and sustainable technology to decontaminate heavy metal polluted water.

Literature is awash with publications about methods to eliminate single metal ion pollutants in water but has comparatively devoted little consideration to explore techniques that purify multi-elements contaminated industry wastewater and effluents. Reference [17] emphasized the importance of wholesome treatment that removes heavy metal ions (typified by multilevel contamination) in aqueous systems.

In Nigeria and other countries characterized by large scale peanut cultivation, large volume, (nearly 0.74 million metric tonnes) of polyphenol-rich, peanut skin or testa is generated as waste from peanut processing industries [18] [19]. This polyphenol-rich peanut testa is rich in catechin [20] [21]. Figure 1 presents the structure of catechin having five hydroxyl groups which are rich in lone pairs.

Despite under-utilization of peanut testa as supplements in animal feeds [22], much of it is littered resulting in a myriad of environmental pollution problems [23] [24]. Consequently, innovative ways to harness this waste for gainful exploitation through creation of value-added products are desirable. Conversion into cation exchange resins for eliminating toxic metal ions in industry wastewater would ensure utilization and validate the tripartite goal of waste minimization, environmental clean-up and wealth creation from peanut testa that has abetted the breeding of nauseating pests. The aim of this study is to investigate the preferential adsorption of $\mathrm{Fe}^{2+}, \mathrm{Ni}^{2+}, \mathrm{Pb}^{2+}, \mathrm{Cu}^{2+}$ and $\mathrm{Zn}^{2+}$ in multi-elements contaminated water using environmentally friendly adsorbents derived from peanut testa extract polyphenols.

\section{Materials and Method}

All the chemicals used in this study were of analytical grade, supplied by Idex Scientific Supplies Company, Ltd, Aba, Nigeria and were used without further purification. The sample collection, processing as well as storage of peanut testa (PT) and the extraction of polyphenols from the PT have been reported [25].

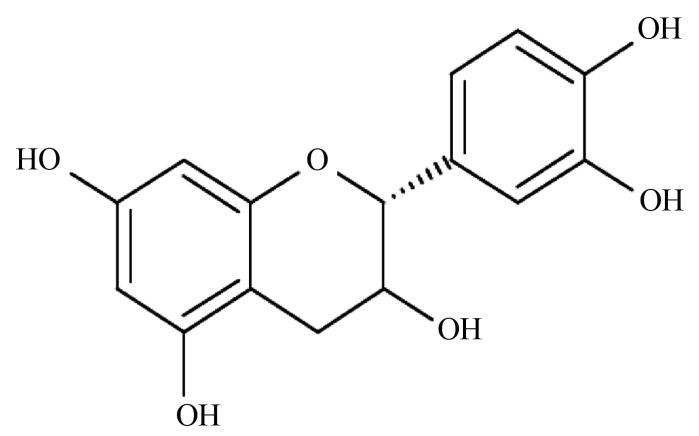

Figure 1. Structure of Catechin. 


\subsection{Preparation of Metal Ion Solutions}

Primary stock solutions containing $100 \mathrm{ppm}$ of the following metal ions: $\mathrm{Zn}^{2+}$, $\mathrm{Pb}^{2+}, \mathrm{Fe}^{2+}, \mathrm{Cu}^{2+}$ and $\mathrm{Ni}^{2+}$ were prepared by dissolving 0.1100, 0.0400, 0.1245, 0 . 0785 and $0.1683 \mathrm{~g}$ of $\mathrm{ZnSO}_{4} \cdot 7 \mathrm{H}_{2} \mathrm{O}, \mathrm{Pb}\left(\mathrm{NO}_{3}\right)_{2}, \mathrm{FeSO}_{4} \cdot 7 \mathrm{H}_{2} \mathrm{O}, \mathrm{Cu}\left(\mathrm{CH}_{3} \mathrm{COO}\right)_{2} \cdot \mathrm{H}_{2} \mathrm{O}$ and $\left(\mathrm{NH}_{4}\right)_{2} \mathrm{SO}_{4} \cdot \mathrm{NiSO}_{4} \cdot 6 \mathrm{H}_{2} \mathrm{O}$ respectively in a little quantity of $\mathrm{DI} \mathrm{H}_{2} \mathrm{O}$ in separate $250 \mathrm{ml}$ volumetric flasks and topping to volume with $\mathrm{DI}_{2} \mathrm{O}$. This gave the individual elements primary stock solutions.

Subsequently, a multi-elements primary stock solution containing $100 \mathrm{ppm}$ of each of the same metal ions was prepared by dissolving the same amount of the corresponding metal salts in a little quantity of $\mathrm{DI}_{2} \mathrm{O}$ in separate $50 \mathrm{~mL}$ beakers and transferring all, together with the rinses to a $250 \mathrm{~mL}$ volumetric flask before diluting to volume with $\mathrm{DI}_{2} \mathrm{O}$.

Thereafter, $10 \mathrm{ppm}$ and $5 \mathrm{ppm}$ working solutions of the individual element solutions and a multi-elements solution were prepared. Five (5) $\mathrm{mL}$ of $50 \% \mathrm{HNO}_{3}$ was added to all the preparations before diluting to volume to prevent precipitation of the metals as salts.

\subsection{Preparation of PTE Resins}

PTE was reacted with $\mathrm{POCl}_{3}$ and CSA through different synthetic procedures to obtain crosslinked, substituted, phospho-sulphonated and sulphonated PTE resins.

\subsubsection{Preparation of Crosslinked-PPTE}

PTE was crosslinked with $\mathrm{POCl}_{3}$ by following the reported procedure [26] as modified [13]. Having stirred PTE $(25 \mathrm{~g})$ in pyridine $(250 \mathrm{~mL})$ held in a $1 \mathrm{~L}$ three-neck flat bottom flask for $12 \mathrm{hrs}$ at RT in a fume hood, the flask was equipped with a thermometer, dropping funnel and a reflux condenser. Thereafter, a freshly prepared mixture consisting of $\mathrm{POCl}_{3}(5 \mathrm{~mL})$ and $25 \mathrm{~mL}$ of dichloromethane (DCM) was added by drops through the funnel over 30 mins. When the set up was clear of fumes, the flask was transferred to a paraffin oil bath and heated at reflux for $3 \mathrm{hrs}$ at $90^{\circ} \mathrm{C}$ with continued stirring. At the end of the process, the oil bath was brought down, the flask detached and set to cool down. The content was poured into a $600 \mathrm{~mL}$ beaker containing $200 \mathrm{~mL}$ of ice $\mathrm{H}_{2} \mathrm{O}$, stirred thoroughly with a glass rod and rapidly filtered on a white band filter paper. The residue was copiously washed, first with $\mathrm{DI}_{2} \mathrm{O}$ until it was free from the smell of pyridine. Again, $100 \mathrm{~mL}$ of $0.1 \mathrm{M} \mathrm{HCl}$ and $\mathrm{DI} \mathrm{H}_{2} \mathrm{O}$ was used until the filtrate tested neutral to methyl red indicator. In the last part, it was washed with $100 \mathrm{~mL}$ of methanol $(\mathrm{MeOH})$ and dried overnight in an oven at $65^{\circ} \mathrm{C}$ to yield $65.43 \% \mathrm{POCl}_{3}$-crosslinked PTE (Crosslinked-PPTE) resin.

\subsubsection{Preparation of Substituted-PPTE}

PTE polyphenols was converted into a cation exchange resin with phosphate $\left(\mathrm{PO}_{4}^{3-}\right)$ end groups through a phosphorylation reaction using a PTE: $\mathrm{POCl}_{3}$ mixture of a different proportion. Substituted-PPTE was synthesized by the proce- 
dure for Crosslinked-PPTE but by adjusting the amount of $\mathrm{POCl}_{3}$ used in the reaction. PTE $(25 \mathrm{~g})$, previously stirred for $12 \mathrm{hrs}$ in pyridine $(250 \mathrm{~mL})$ was reacted with a freshly prepared mixture consisting of $\mathrm{POCl}_{3}(15 \mathrm{~mL})$ in DCM $(90$ $\mathrm{mL}$ ). The $\mathrm{POCl}_{3}$-DCM mixture was added by drops over $1 \frac{1 / 2}{2} \mathrm{hrs}$ and the rest of the procedure for the preparation of Crosslinked-PPTE followed to obtain $71.05 \%$ of $\mathrm{POCl}_{3}$-substituted PTE (Substituted-PPTE) resin.

\subsubsection{Sulphonation of Crosslinked-PPTE Using CSA (PS-PTE)}

Functionalization of Crosslinked-PPTE using CSA was achieved through an adjustment of the method described and reported [13] [27]. Crosslinked-PPTE (25 g) was stirred to homogeneity in pyridine $(250 \mathrm{~mL})$ at RT according to the method for preparing Crosslinked-PPTE and Substituted-PPTE. After adding a freshly prepared mixture of CSA $(5 \mathrm{~mL})$ in DCM $(40 \mathrm{~mL})$ by drops, the rest of the procedure was followed to obtain $68.54 \%$ of $\mathrm{POCl}_{3}$-crosslinked and sulphonated-PTE (PS-PTE) resin.

\subsubsection{Sulphonation of PTE (SU-PTE)}

The phenolic groups in PTE polyphenols were adapted to $-\mathrm{SO}_{3} \mathrm{H}^{-}$groups by treating with CSA according to the procedure for the phosphorylation of same but by reacting PTE $(25 \mathrm{~g})$ stirred in pyridine $(250 \mathrm{~mL})$ with CSA $(8 \mathrm{~mL})$ in DCM $(40 \mathrm{~mL})$ mixture. The yield was $76.87 \%$ of sulphonated-PTE (SU-PTE) re$\sin$.

\subsection{Resins Characterization}

The techniques used for the characterization of the synthesized resins, the starting materials and Bio-Rex 70 together with the instrument used, the models and operational ranges have been reported [25].

\subsection{Ion Exchange and Adsorption Studies}

Prior to use for the individual batch adsorption experiments, PT, PTE, Crosslinked-PPTE, Substituted-PPTE and PS-PTE as well as SU-PTE and Bio-Rex 70 were converted to the hydrogen ion $\left(\mathrm{H}^{+}\right)$forms (activation) by filtering and washing to neutrality, an overnight dilute $\mathrm{HNO}_{3}$ saturated portion and oven drying for $4 \mathrm{hrs}$ at $60^{\circ} \mathrm{C}$. Then, each $\mathrm{HNO}_{3}$ activated adsorbent $(1 \mathrm{~g})$ was transferred into separate $50 \mathrm{~mL}$ solution containing $10 \mathrm{ppm}$ of $\mathrm{Zn}^{2+}, \mathrm{Pb}^{2+}, \mathrm{Fe}^{2+}, \mathrm{Cu}^{2+}$, and $\mathrm{Ni}^{2+}$ in a plastic bottle. $5 \mathrm{~g}$ of each resin and Bio-Rex 70 was also transferred into separate $50 \mathrm{~mL}$ of the multi-elements solution containing $10 \mathrm{ppm}$ of the metal ions in five different batch set-ups. Finally, 2.5 and $50 \mathrm{~g}$ of PS-PTE resin was transferred into separate $100 \mathrm{~mL}$ multi-elements solutions containing 5 and 100 ppm respectively of the metal ions in two other set-ups. The $\mathrm{pH}$ of the solutions which were administered using different delivery pipettes was determined and adjusted to $6 \pm 0.5$ with $0.1 \mathrm{M} \mathrm{HCl}$ or $0.1 \mathrm{M} \mathrm{NaOH}$ before the introduction of the resins. The caps were immediately secured, the bottles positioned on a Nuve SL 250 horizontal bench shaker and agitated at $150 \mathrm{rpm}$ (revolutions per minute) 
for 2 hrs at RT. Thereafter, the bottles were unfastened and the suspensions rapidly filtered on separate Whatman No. 44 folded filter paper. The concentration of each metal ion in the filtrates was determined using Flame Atomic Absorption Spectrophotometer (AAS) and the amount of the metal ion (ppm) removed from the solutions by individual adsorbents at equilibrium $Q_{e}$, computed from the model given in Equation (1):

$$
Q_{e}=\frac{C_{o}-C_{e}}{W} \times V
$$

where: $C_{o}$ and $C_{e}$ are the initial concentration and concentration (ppm) of the metal ion in the solution at equilibrium while $V$ and $W$ respectively are the volume of the solution and the weight of the adsorbent $(\mathrm{g})$ used in the experiment.

\section{Results and Discussion}

\subsection{Modification with $\mathrm{POCl}_{3}$}

The modification of PTE with the electrophilic reagent $\mathrm{POCl}_{3}$ as reported [25]; took place via the polycondensation of PTE polyphenol units (demonstrated using catechin molecule) by the interaction between the hydroxyl hydrogen $(\mathrm{H})$ of the catechin and $\mathrm{Cl}^{-}$of $\mathrm{POCl}_{3}$. The reaction progressed by two distinct routes, to yield Crosslinked-PPTE and Substituted-PPTE. In order to obtain the former, $\mathrm{POCl}_{3}$ reacted at a single $-\mathrm{OH}$ site of adjacent catechins, condensed them into a bridge with the elimination of $\mathrm{HCl}$ molecules. This resulted to the formation of a -P-O- bond of a phosphate ester $\left(-\mathrm{PO}_{4}^{3-}\right)$ on either sides of the newly created $-\mathrm{P}=\mathrm{O}$ bond on catechins and a replaceable $-\mathrm{OH}$ group (a PTE phospho-monoanion). Substituted-PPTE, on the other hand, formed when $\mathrm{POCl}_{3}$ reacted with an $\mathrm{OH}$ group of a unit PTE catechin, substituting the phenolic hydrogen $(\mathrm{H})$ and replacing it with a terminal $\mathrm{PO}_{4}^{3-}$ group with two ionisable -OH groups (PTE phosphor-di-anion). The reactions for the formation of the CrosslinkedPPTE (a) and Substituted-PPTE (b) are illustrated in Scheme 1.

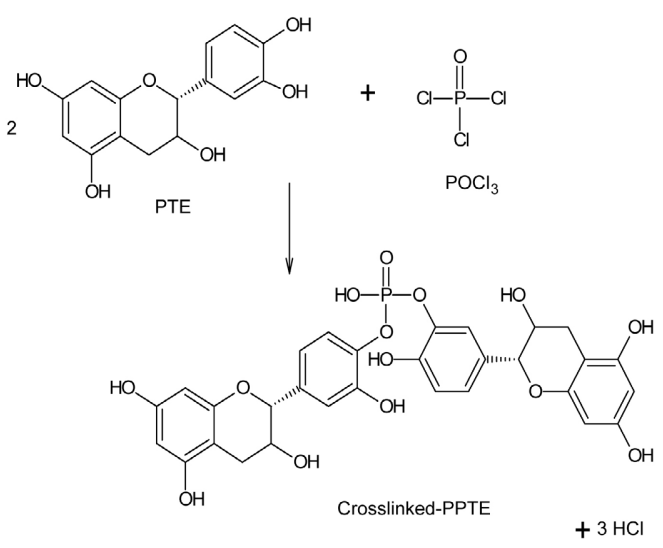

(a)

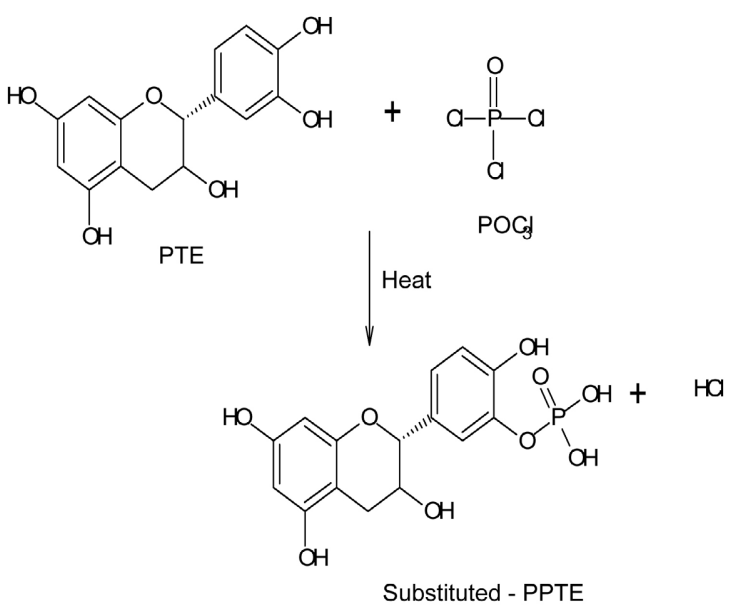

(b)

Scheme 1. Formation of Crosslinked-PPTE (a) and Substituted-PPTE (b). 


\subsection{Sulphonation of PTE and Crosslinked-PPTE with CSA (SU-PTE and PS-PTE)}

Functionalization of PTE and Crosslinked-PPTE was accomplished by direct sulphonation using CSA. In the case of Crosslinked-PPTE, the process boosted the electron density around the $-\mathrm{P}=\mathrm{O}$ bond through an electrophilic substitution that replaced the hydroxyl hydrogens $(\mathrm{H})$ in PTE-catechins and CrosslinkedPPTE with negatively charged $\mathrm{HSO}_{3}^{-}$groups. The reaction paths leading to the conversion of PTE and Crosslinked-PPTE to SU-PTE and PS-PTE respectively are shown in Scheme 2 and had been reported [25].

\subsection{FTIR Spectra of PT and PTE}

Table 1 outlines the characteristic absorption bands found in the FTIR spectra of PT and PTE [28]. The broad bands at $3431 / 3423 \mathrm{~cm}^{-1}$ and the medium peaks at $1377 / 617 \mathrm{~cm}^{-1}$ respectively are ascribed to stretching and in- and -out-ofplane bending movements of - $\mathrm{OH}$ groups of the polyphenol (which are $5 \mathrm{in} \mathrm{ca-}$ techin) units of these starting materials. The 2 IR bands found at 2928/2926 $\mathrm{cm}^{-1}$ and the lone band at $1142 \mathrm{~cm}^{-1}$ are due to stretching and bending of the $\mathrm{sp}^{3}$ -C-H bond of the cyclic ether middle ring of testa catechins. The two IR absorption bands at 1629 and $1528 \mathrm{~cm}^{-1}$ are credited to $-\mathrm{C}=\mathrm{C}$ - bonds in the adjacent rings of catechin and whereas the $-\mathrm{C}-\mathrm{O}-\mathrm{C}$ - stretch of the cyclic ether central ring absorbed IR radiation at $1160 / 1034 \mathrm{~cm}^{-1}$, absorption bands due to its $-\mathrm{C}-\mathrm{H}$ stretch showed at $823 / 668 \mathrm{~cm}^{-1}$.

\subsection{FTIR Spectra of Modified PTE Resins}

In addition to the absorption bands in the 3400,2900 and $1600 \mathrm{~cm}^{-1}$ regions corresponding to the $-\mathrm{OH},-\mathrm{CH}_{2}$ and $-\mathrm{CH}$ groups of the starting material which also showed in the spectra of all the products, the synthesized resins displayed additional IR absorption bands [28] between 1400 and $900 \mathrm{~cm}^{-1}$ depending on the reagent with which the chemical modification was performed.

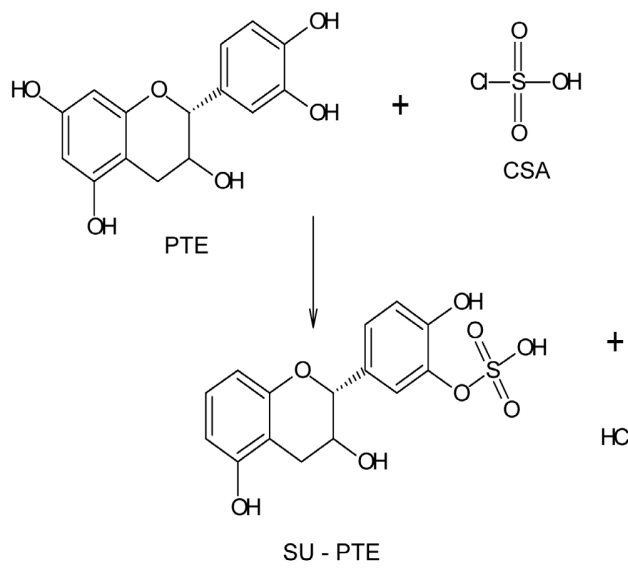

(a)

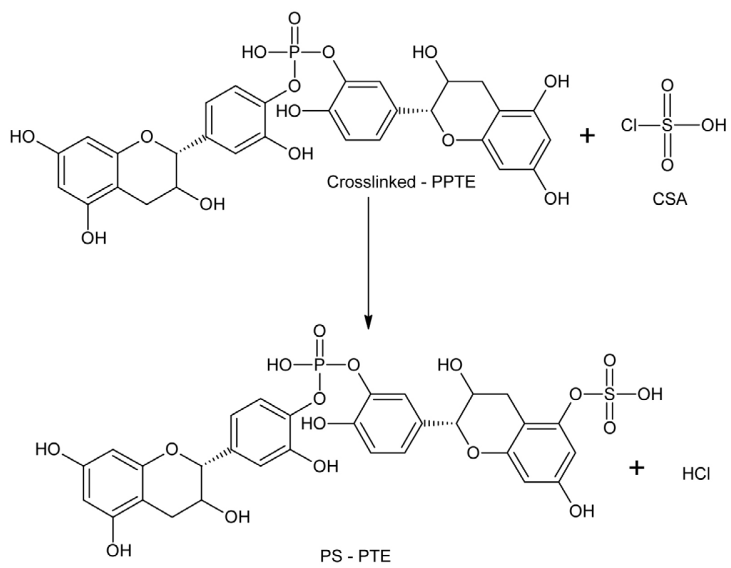

(b)

Scheme 2. Formation of SU-PTE (a) and PS-PTE (b). 
Table 1. Characteristics bands in the FTIR spectra of PT and PTE.

\begin{tabular}{|c|c|c|}
\hline $\begin{array}{l}\text { Frequency } \\
\qquad\left(\mathrm{cm}^{-1}\right)\end{array}$ & Origin/Type of Vibration & Functional Group Assignment \\
\hline $3431 / 3423$ & $\begin{array}{l}\text { Stretching vibration of } \mathrm{O}-\mathrm{H} \\
\text { group in } \mathrm{R}-\mathrm{OH} \text { and } \mathrm{Ph}-\mathrm{OH}\end{array}$ & $\begin{array}{l}\text { Thought to come from -O-H } \\
\text { of PT/PTE polyphenols e.g., } \\
\text { catechin. }\end{array}$ \\
\hline $2928 / 2926$ & $\begin{array}{l}2 \text { bands. Stretching vibration } \\
\text { of a }-\mathrm{C}-\mathrm{H}\left(\mathrm{sp}^{3}\right) \text { bond in alkyls }\end{array}$ & $\begin{array}{l}\text { Supposedly from -C-H bonds } \\
\text { in the saturated parts of PT- } \\
\text { catechin rings. }\end{array}$ \\
\hline $1629 / 1528$ & $\begin{array}{l}2 \text { bands. Stretching of a } \\
-C=C-\text { bond in a ring }\end{array}$ & $\begin{array}{l}\text { Certainly from the unsaturated } \\
\text { side rings of PT/PTE catechins. } \\
\text { The conjugation is remarkably } \\
\text { incomplete since it is absent in the } \\
\text { middle ring, otherwise, there } \\
\text { would have presented as } 3 \text { bands. }\end{array}$ \\
\hline 1377 & $\begin{array}{l}\text { Medium peak. In-plane } \\
\text { bending of -OH }\end{array}$ & $\begin{array}{l}\text { Attributable to in-plane-bending } \\
\text { movement of -OH groups of PT } \\
\text { catechin units. That due to the } \\
\text { out-of-plane stretch was seen at } \\
617 \mathrm{~cm}^{-1} \text {. }\end{array}$ \\
\hline 1142 & $-\mathrm{C}-\mathrm{H}\left(\mathrm{Sp}^{3}\right)$ bending & $\begin{array}{l}\text { Conceivably from the } \alpha \text { - } \mathrm{CH}_{2}- \\
\text { bond of the partially saturated } \\
\text { middle ring of PT catechins. }\end{array}$ \\
\hline $1160 / 1034$ & $\begin{array}{l}\text {-C-O-C- stretchof a large cyclic } \\
\text { ethers-i.e. alkoxy group }\end{array}$ & $\begin{array}{l}\text { Likely from the -C-O- of the } \\
\text { ether bearing middle ring of } \\
\text { PT catechins. }\end{array}$ \\
\hline $823 / 668$ & $\begin{array}{l}\text { C-H- stretch of aromatic and } \\
\text { substituted aromatics. }\end{array}$ & $\begin{array}{l}\text { Presumably from the aromatic } \\
\text { rings of PT catechins; ortho and } \\
\text { para di-substituted aromatic rings }\end{array}$ \\
\hline
\end{tabular}

From the results obtained the intensities of the $-\mathrm{OH}$ stretches at 3431/3423 and $1377 / 617 \mathrm{~cm}^{-1}$ (Table 1) were higher in all the starting materials when compared to the products formed (Table 2 and Table 3 ). The intensities of the absorption bands due to stretching and in-plane and out-of-plane bending movements of the different -OH groups in the spectra of Substituted-PPTE; Crosslinked-PPTE; PS-PTE; SU-PTE and PTE were 3.5 and 3.9; 3.4 and 3.7; 3.4 and $3.8 ; 3.3$ and 3.6 and 1.8 and 2.4 respectively.

A polymer is a high molecular weight substance resulting from a systematic arrangement of numerous repeat units within a chain structure while a monomer is the basic unit or group of units (in case of a co-polymer) that is repeated in the chain. In the present study, PTE catechin units are the monomers while the two crosslinked products: Crosslinked-PPTE and PS-PTE represent the polymers. The observed increased intensities of the - $\mathrm{OH}$ absorption bands in these products is a consequence of the bridge created during the crosslinking of PTE catechin units to produce the Crosslinked-PPTE polymer. Moreover, the 
Table 2. Characteristics bands in the FTIR spectra of Crosslinked-PPTE and substitutedPPTE.

\begin{tabular}{|c|c|c|}
\hline Frequency $\left(\mathrm{cm}^{-1}\right)$ & Origin/Type of Vibration & Functional Group Assignment \\
\hline $2692 / 2546$ & $\begin{array}{l}\text {-OH stretching of a } \\
\text { phosphonic acid; } \mathrm{O}=\mathrm{P}-\mathrm{O}-\mathrm{H}\end{array}$ & $\begin{array}{l}\text { Assumed to have come from the } \\
\mathrm{O}=\mathrm{P}-\mathrm{O}-\mathrm{H} \text { bond created in } \\
\text { Crosslinked-PPTE and } \\
\text { Substituted-PPTE during } \\
\text { modification. The intensity of the } \\
\text { absorption band in } \\
\text { Substituted-PPTE was twice that } \\
\text { in Crosslinked-PPTE. }\end{array}$ \\
\hline $1350 / 1250$ & $\begin{array}{l}-\mathrm{R}-\mathrm{O}-\mathrm{P}=\mathrm{O} \text { stretch of organic } \\
\left(\mathrm{PO}_{4}^{3-}\right) \text { phosphates }\end{array}$ & $\begin{array}{l}\text { P-containing organic compounds } \\
\text { are characterized by IR absorption } \\
\text { in this region. These absorptions } \\
\text { bands are not present in the IR } \\
\text { spectra of the starting materials, } \\
\text { thus lending credence to the } \\
\text { formation of new chemical bonds } \\
\text { and successful modification of } \\
\text { PTE polyphenol swith } \mathrm{POCl}_{3} \text {. }\end{array}$ \\
\hline $1198 / 1087$ & $-\mathrm{P}=\mathrm{O}$ stretch & $\begin{array}{l}\text { Supposedly from the } \\
\text { new-PTE--P=O bond, } \\
\text { presumably formed between } \mathrm{O}-\mathrm{H} \\
\text { of PTE catechins and } \mathrm{P} \text { of } \mathrm{POCl}_{3} \\
\text { in the crosslinking or substitution } \\
\text { processes. }\end{array}$ \\
\hline $997 / 993$ & $\begin{array}{l}-\mathrm{C}-\mathrm{O}-\mathrm{P} \text { - stretch of }\left(\mathrm{PO}_{4}^{3-}\right) \\
\text { phosphate esters }\end{array}$ & $\begin{array}{l}\text { Most likely from the } \\
\text { R-O-P- bond created in the } \\
\text { crosslinking or substitution } \\
\text { processes. }\end{array}$ \\
\hline
\end{tabular}

Table 3. Characteristics bands in the FTIR Spectra of PS-PTE and SU-PTE.

\begin{tabular}{|c|c|c|}
\hline Frequency $\left(\mathrm{cm}^{-1}\right)$ & Origin/Type of Vibration & Functional Group Assignment \\
\hline $2700-2550$ & $\begin{array}{l}\text {-OH stretch of } \\
\text { phosphonic acid; } \\
\mathrm{H}-\mathrm{O}-\mathrm{P}=\mathrm{O}\end{array}$ & $\begin{array}{l}\text { Suspected to come from } \\
\mathrm{H}-\mathrm{O}-\mathrm{P}=\mathrm{O} \text { bonds created } \\
\text { during the formation of } \\
\text { Crosslinked-PPTE. }\end{array}$ \\
\hline $1260 / 1230$ & $\begin{array}{l}-\mathrm{C}-\mathrm{O}-\mathrm{P}=\mathrm{O} \text { stretch of organic } \\
\left(\mathrm{PO}_{4}^{3-}\right) \text { phosphates }\end{array}$ & As for Crosslinked-PPTE. \\
\hline $1200 / 1100$ & $-\mathrm{P}=\mathrm{O}$ stretch & Ditto. \\
\hline $1050 / 970$ & $\begin{array}{l}-\mathrm{P}-\mathrm{O}-\mathrm{C} \text { - stretch of }\left(\mathrm{PO}_{4}^{3-}\right) \\
\text { phosphate esters. }\end{array}$ & Ditto. \\
\hline $1420-1100$ & $\begin{array}{l}\text { Aryl sulphones, organic } \\
\text { sulphates and sulphonates } \\
\text { demonstrate IR absorption } \\
\text { in this region. }\end{array}$ & $\mathrm{SO}_{2},-\mathrm{SO}_{4}$, etc. \\
\hline
\end{tabular}




\section{Continued}

\begin{tabular}{lll}
\hline $1450-1345$ & $\begin{array}{l}\text { Asymmetric stretch of the } \\
-\mathrm{S}=\mathrm{O} \text { group of }-\mathrm{SO}_{3} \mathrm{H}^{-} \\
\text {and }-\mathrm{SO}_{4}^{2-}\end{array}$ & $\begin{array}{l}\text { Sulphonic acid }\left(-\mathrm{SO}_{3} \mathrm{H}^{-}\right) \text {group } \\
\text { introduced to substitute for and } \\
\text { replace the hydroxyl } \\
\text { hydrogens }(\mathrm{H}) \text { of } \mathrm{PTE} \text {-catechin } \\
\text { in the sulphonationprocess. }\end{array}$ \\
$1323-1300$ & $\begin{array}{l}\text { Asymmetric stretching of } \\
\mathrm{O}=\mathrm{S}-\text { of }(\mathrm{O}=\mathrm{S}=\mathrm{O}) \text { sulphones }\end{array}$ & $\begin{array}{l}\text { Sulphone } \mathrm{O}=\mathrm{S}=\mathrm{O} \text { bond created } \\
\text { in the sulphonation process. }\end{array}$ \\
$1160-1125$ & $\begin{array}{l}\mathrm{Symmetric} \text { stretching of } \\
\mathrm{O}=\mathrm{S}-\text { of } \mathrm{O}=\mathrm{S}=\mathrm{O}\end{array}$ & $\begin{array}{l}\text { PTE-O-S-O-H created during } \\
\text { sulphonation. }\end{array}$ \\
\hline
\end{tabular}

collective intensity of the -OH groups in a Crosslinked-PPTE polymer chain (PTE-O-P-O-PTE $)_{n}$ offsets the intensity of the $5-\mathrm{OH}$ groups of individual PTE catechin units. In addition, the contributions by the - $\mathrm{OH}$ groups of the phosphonic, sulphenic and sulphonic acids as well as those of the phosphates, sulphone and sulphates may have further boosted the strength of the - $\mathrm{OH}$ absorption bands.

While the IR bands in the 1200 and $960 \mathrm{~cm}^{-1}$ region are assignable [28] to the -C-O-P- stretch of phosphate esters in Crosslinked and PS-PTE, these bands are not present in the spectra of Substituted-PPTE. The intensity of the -C-O-P- absorption band showed to be higher in the spectra of Crosslinked-PPTE relative to that of Substituted-PPTE. This is due to the effect of the twin -C-O-P- bonds contributed by the R-O-P-O-R bond of individual catechin units in CrosslinkedPPTE against the lone -C-O-P- bond in Substituted-PPTE.

IR absorption bands ascribed to the asymmetric stretch of the $-\mathrm{S}=\mathrm{O}$ bond of the $\mathrm{HSO}_{3}^{-}$and $\mathrm{SO}_{4}^{2-}$ groups were seen at $1450 / 1345 \mathrm{~cm}^{-1}$ while the same for the asymmetric and symmetric stretch correspondingly of the $\mathrm{O}=\mathrm{S}$ - bond in $\mathrm{O}=\mathrm{S}=\mathrm{O}$ showed at $1323 / 1300$ and $1160 / 1125 \mathrm{~cm}^{-1}$ in the spectra of PS-PTE and SU-PTE.

While PS-PTE produced absorption bands conforming to IR movements at eight locations, including 2700/2550;1260/230; 1200/1100 and 1050/970 as well as $1410 ; 1450 / 1345 ; 1323-1300 ; 1160-1125$ and $1062-1034 \mathrm{~cm}^{-1}$ respectively confirming the presence of all H-O-P=O; -C-O-P=O-; -P=O; -P-O-C-; C-O-S; $\mathrm{O}=\mathrm{S}=\mathrm{O} ;-\mathrm{SO}_{4}^{2-}, \quad-\mathrm{SO}_{3} \mathrm{H}^{-}$and $-\mathrm{S}-\mathrm{O}-\mathrm{H}$ functional groups in the same molecule, IR absorption bands present at 1420/1100; 1450/1345; $1323-1300 ; 1160-1125$ and $1062-1034 \mathrm{~cm}^{-1}$ suggest the presence of $-\mathrm{C}-\mathrm{O}-\mathrm{S} ; \mathrm{O}=\mathrm{S}=\mathrm{O} ; \quad-\mathrm{SO}_{4}^{2-}, \quad-\mathrm{SO}_{3} \mathrm{H}^{-}$ and $-\mathrm{S}-\mathrm{O}-\mathrm{H}$ groups in the spectra of SU-PTE.

\subsection{Adsorption of Metal Ions by PT, PTE, PTE Cation Exchange Resins and Bio-Rex 70 in Element Solutions}

PTE consists of several polyphenol/catechin units hosting multiple -OH groups that yield to modification at suitable conditions. Modification can be achieved 
through a variety of processes including, physical and chemical techniques such as crosslinking, substitution and incorporation of new functional groups. The incorporated chemical groups produced new exchange sites on PTE and improved the capacity of the produced resins to adsorb metal ions from the different solutions. The percentages of $\mathrm{Fe}^{2+}, \mathrm{Ni}^{2+}, \mathrm{Pb}^{2+}, \mathrm{Cu}^{2+}$ and $\mathrm{Zn}^{2+}$ removed by PT, PTE, the resins and Bio-Rex 70 are presented on Table 4. The result shows that apart from Bio-Rex 70, PTE resins developed through chemical modification with $\mathrm{POCl}_{3}$ were more effective in removing nearly all the metal ions in the solutions in contrast to that obtained through functionalizing alone.

As a bi-functional reagent, $\mathrm{POCl}_{3}$ reacts with - $\mathrm{OH}$ group containing molecules in two distinct ways to produce two different products. It crosslinks or substitutes an - $\mathrm{OH}$ group in a compound to form a product which contains mono-anion or di-anion $\mathrm{PO}_{4}^{3-}$ groups. The presence of these groups on the surfaces of $\mathrm{POCl}_{3}^{-}$ modified PTE cation exchange resins and the absence of the di-anion on the surface of that modified with CSA alone explains the disparate adsorption efficiency in favour of PS-PTE, Crosslinked-PPTE and Substituted-PPTE over SUPTE.

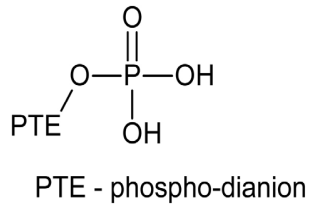<smiles>CC(C)OP(=O)(O)OC(C)C</smiles>

PTE - phospho-monoanion<smiles>CC(C)OS(=O)(=O)O</smiles>

PTE - sulpho-monoanion

Among the $\mathrm{POCl}_{3}$-modified resins, PS-PTE demonstrated the highest metal ion adsorption ability over Crosslinked-PPTE and Substituted-PPTE and this is a consequence of the combined presence of the $\mathrm{SO}_{3} \mathrm{H}^{-}$and $\mathrm{PO}_{4}^{3-}$ groups in the resin molecule. In addition to high polar nature of both groups, the presence of lone pair electrons on the $\mathrm{O}=\mathrm{S}=\mathrm{O}$ and $-\mathrm{P}=\mathrm{O}$ bonds increased the electron density around the groups and thereby increased the affinity of the groups for the positive metal ions in the solutions. References [29] [30] [31] observed

Table 4. Percent removal of $\mathrm{Fe}^{2+}, \mathrm{Ni}^{2+}, \mathrm{Pb}^{2+}, \mathrm{Cu}^{2+}$ and $\mathrm{Zn}^{2+}$ by PT, PTE, PTE resins and Bio-Rex 70 in element solutions.

\begin{tabular}{cccccc}
\hline Resin Identity & $\% \mathrm{Fe}^{2+}$ & $\% \mathrm{Ni}^{2+}$ & $\% \mathrm{~Pb}^{2+}$ & $\% \mathrm{Cu}^{2+}$ & $\% \mathrm{Zn}^{2+}$ \\
\hline PT & 15.2 & 19.5 & 6.9 & 13.8 & 16.6 \\
PTE & 6.7 & 8.1 & 0 & 7.08 & 12.4 \\
Crosslinked-PTE & 84.4 & 81.7 & 76.5 & 72.0 & 75.1 \\
Substituted-PTE & 79.8 & 76.8 & 72.6 & 67.9 & 69.3 \\
PS-PTE & 83.1 & 88.7 & 81.7 & 84.3 & 81.5 \\
SU-PTE & 71.7 & 70.7 & 67.4 & 63.7 & 61.2 \\
Bio-Rex 70 & 81.8 & 91.7 & 84.8 & 88.7 & 85.3 \\
\hline
\end{tabular}


enhanced metal ion binding capacities demonstrated by bi-functional phosphosulphonated cation exchange resins reportedly synthesized via different techniques.

Branching and the presence of plurality of $\mathrm{PO}_{4}^{3-}$ pendants due to created -C-O-P- bonds in crosslinked phosphorylated wood pulp against uncrosslinked phosphorylated wood pulp was explained [17] as reasons for the observed higher adsorption of the different metal ions by the former rather than the later. The intensities of the -C-O-P- absorption bands captured from the FTIR spectra of Crosslinked-PPTE and Substituted-PPTE in the current study are10.7 and 4.2 respectively, signifying a larger than 2:1 ratio of the presence of -C-O-P- bonds between the two products. This difference in the intensities of the -C-O-P- absorption bands in the spectra of the two resins accounts for the superior performance of Crosslinked-PPTE as an adsorbent for the investigated metal ions to Substituted-PPTE.

As electronegativity increases across a period in the periodic table of the elements, higher electronegative $S$ (2.5) should more readily attract positively charged metal ions to form metal-S- bonds than would P (2.1) under similar conditions to form metal-P- bonds. Moreover, the intensity of the $\mathrm{O}=\mathrm{S}=\mathrm{O}$ absorption band at $1420 \mathrm{~cm}^{-1}$ which was found to be higher than that of the $-\mathrm{P}=\mathrm{O}$ at $1246 \mathrm{~cm}^{-1}$ indicatesthat more $-\mathrm{S}=\mathrm{O}$ groups attached to the PTE catechin units in the $\mathrm{SO}_{4}^{2-}$ monoester than $-\mathrm{P}=\mathrm{O}$ groups attached to the polyphenol units in the phosphorylated resin. Notwithstanding, the presence of 3 electron withdrawing/seeking groups, i.e. $2-\mathrm{OH}$ and a unit $-\mathrm{P}=\mathrm{O}$ groups on Substituted-PPTE empowers it to attract and hold on to higher amounts of the positively charged metal ions in the solutions than SU-PTE. Therefore, Substituted-PPTE, a PTE-di-anion seized and eliminated more of the metal ions in the solutions than SU-PTE, a PTE-monoanion.

Furthermore, the effectiveness of PTE cation exchange resins derived through modification using $\mathrm{POCl}_{3}$ or CSA alone or both $\mathrm{POCl}_{3}$ and CSA remarkably followed the trend: CSA < Substituted-PPTE < Crosslinked-PPTE < PS-PTE suggesting a correlation between the ion exchange capacity (IEC) of a resin and the type and magnitude of the ionisable groups on it. The findings from the current research validate that reported [17] about higher $\mathrm{Zn}^{2+}, \mathrm{Pb}^{2+}, \mathrm{Fe}^{2+}, \mathrm{Ni}^{2+}$ and $\mathrm{Cr}^{2+}$ adsorption efficiencies by phosphosulphonated over phosphorylated crosslinked, phosphorylated but not crosslinked and sulphonated corncobs.

All the modified resins showed to remove higher amounts of the metal ions in the solutions than PT and PTE because, in the case of Crosslinked-PPTE, the adsorption capacity is a summation of the adsorption capacities of individual polyphenol/catechin units which joined to form it. Chemical modification of an adsorbent improves the uptake of metal ions by increasing the number of accessible sites on the adsorbent, imparting superior ion exchange properties and enhancing its adsorption capacity. The enhanced metal ions adsorption demonstrated by modified PTE polyphenols against the starting materials is ascribed to the different functional groups, including, $-\mathrm{P}=\mathrm{O},-\mathrm{C}-\mathrm{O}-\mathrm{S}, \mathrm{O}=\mathrm{S}=\mathrm{O},-\mathrm{SO}_{3} \mathrm{H}^{-}$, 
$\mathrm{S}-\mathrm{OH}, \mathrm{SO}_{4}^{2-},-\mathrm{P}-\mathrm{OH}, \mathrm{O}=\mathrm{P}-\mathrm{OH}$ which were incorporated on testa. The groups increased the acidity of the adsorbate solutions and in synergy with the unreacted $-\mathrm{OH}$ andphenolic $\left(-\mathrm{C}_{6} \mathrm{H}_{5}\right)$ groups of PTE polyphenols contributed to the relatively higher affinity of the synthesized cation exchange resins for the different metal ions. These, in addition to increased polarity and electronegativity of the added groups are presented for the outbalanced performances of the modified PTE adsorbents over the starting materials.

Furthermore, PT, PTE and the cation exchange resins observably removed the metal ions in a particular trend. Apart from PS-PTE and the starting materials, $\mathrm{PT}$ and PTE which removed more $\mathrm{Cu}^{2+}$ than $\mathrm{Zn}^{2+}, \mathrm{Ni}^{2+}$ than $\mathrm{Fe}^{2+}$ and $\mathrm{Pb}^{2+}$ than $\mathrm{Ni}^{2+}, \mathrm{Fe}^{2+}>\mathrm{Ni}^{2+}>\mathrm{Pb}^{2+}>\mathrm{Zn}^{2+}>\mathrm{Cu}^{2+}$ was the order by which the rest of the modified resins eliminated the metal ions in the solutions. Catechin is known for its excellent chelate formation with Fe. Reference [32] reported the influences of electrical charge and ionic radius as well as electronegativity of a metal and stearic conformation of the resulting metal-ion-resin-complex on the IEC, metal ion affinity of different functional groups and the amount of the metal ion in a solution which can be removed by a cation exchange resin. Substantiating, reported preferential adsorption of $\mathrm{Hg}^{2+}$ above $\mathrm{Cd}^{2+}$ and $\mathrm{Pb}^{2+}$ by 6-poly-dimethylaminoethyl-methacrylate-rice-straw (PDMAEMRS) grafted copolymers attributable to the former's atomic size, ionic charge and interaction with other constituents of the solution.

The ionic radius of an element conveys the extent of its ionic size or the mean distance from the centre of its nucleus to the boundary of the closest electron cloud. $\mathrm{Fe}^{2+}, \mathrm{Ni}^{2+}, \mathrm{Zn}^{2+}, \mathrm{Cu}^{2+}$ and $\mathrm{Pb}^{2+}$ respectively are characterized by ionic radii of $0.65 \AA, 0.69 \AA, 0.74 \AA, 0.73 \AA$ and $1.19 \AA$. Besides $\mathrm{Pb}^{2+}, \mathrm{Fe}^{2+}, \mathrm{Ni}^{2+}, \mathrm{Zn}^{2+}$ and $\mathrm{Cu}^{2+}$ belong to the $4^{\text {th }}$ period in the periodic table of the elements and although individual ionic radii do not significantly differ from one another, progress of the order: $\mathrm{Fe}^{2+}<\mathrm{Ni}^{2+}<\mathrm{Cu}^{2+}<\mathrm{Zn}^{2+}$ obtains. While others [10] attributed the favourable adsorption of $\mathrm{Mg}^{2+}$ over $\mathrm{Cd}^{2+}, \mathrm{Zn}^{2+}, \mathrm{Cu}^{2+}$ and $\mathrm{Pb}^{2+}$ by alkaline treated 2, 4-dichloro-6-(phenoxy-4-sulphonic acid)-1,3,5- triazine-orange mesocarpextract resin to the small ionic size of $\mathrm{Mg}^{2+}$, the higher affinity for $\mathrm{Cu}^{2+}$ of smaller ionic size, demonstrated by - $\mathrm{OH}$ and - $\mathrm{SH}$ ligands in untreated and acid treated cassava (manihot esculentacranz) waste was acknowledged by other reports [33] for its preferential adsorption from solution over $\mathrm{Zn}^{2+}$. Likewise, the smaller ionic sizes of $\mathrm{Fe}^{2+}$ and $\mathrm{Ni}^{2+}$ relative to the other ions are presented for the preferential adsorption of the duo from the solutions by the PTE cation exchangers under investigation.

Although the removal of the metal ions by PTE and its derivatives seemingly followed a particular trend, PS-PTE and Crosslinked-PPTE demonstrated the highest $\mathrm{Pb}^{2+}$ adsorption while the converse was the case by PT and PTE. In addition to enhanced capacity imparted through chemical modification, report [34] indicates that affinity of $-\mathrm{SO}_{3} \mathrm{H}^{-}$resins for metal ions is highest for ions of large ionic radii like $\mathrm{Pb}^{2+}$ may explain the remarkable $\mathrm{Pb}^{2+}$ binding capacity observed for PS-PTE. In the case of Crosslinked-PPTE, the amount of $\mathrm{Pb}^{2+}$ re- 
moved was basically a demonstration of the combined adsorption strengths of the individual PTE monomer units in the polymer.

The results also showed that PT removed more of the metal ions than PTE. This is attributed to the difficulty of the large ionic radius $\mathrm{Pb}^{2+}$ to migrate, attach and secure to the binding sites of jelly PTE while the other metal ions of comparatively smaller sizes held only loosely, whereas, all bound to PT, albeit, little (relative to the amounts bound by the modified PTEs) by a mutual strength of the rough macroporous and smooth jelly polyphenols.

Notwithstanding, PTE polyphenols was extracted before modification to downplay the association between the different biomass constituents reported [35] for the observed comparatively little integration of chemical groups on banana leaves.

\subsection{Adsorption of Metal Ions in a Multi-Elements Solution and the Effect of Competing Metal Ions in Solutions of Low and High Metal Ions Concentration}

Industry wastewater and discharges contain several heavy metal ions as pollutants. It is essential to evaluate the adsorption of each pollutant in real world situations. In such circumstances, metal ions in a solution compete with one another for the limited adsorption sites on an adsorbent's surface with the preference of the adsorbent for individual metal ions remotely sufficient to suggest the amount of a metal ion that would bind to the particular adsorbent under competitive conditions. Not even the metal complexation and chelation prospects of an adsorbent can confidently describe its behaviour in a multi-element system challenged by interplay between metal ions competing for binding sites on an adsorbent. Adsorption of heavy metal ions in a multi-element system depends not only on adsorbent surface properties and adsorbate solution chemistry and properties, but on the magnitude as well as type and strength of the different metal ions competing for the active sites on the adsorbent. Adsorption capacity of an ion exchange resin (IER) for every contaminant heavy metal in an industry waste stream must be established before selecting a particular resin if optimum performance is to be achieved. The results of the adsorption of $\mathrm{Fe}^{2+}$, $\mathrm{Ni}^{2+}, \mathrm{Pb}^{2+}, \mathrm{Cu}^{2+}$ and $\mathrm{Zn}^{2+}$ in a multi-elements solution and the preference of modified PTE cation exchange resins and Bio-Rex 70 for a metal ion over another in a competitive environment is presented on Table 5 while the graphical illustration of the comparison of the affinity of PS-PTE resin for the metal ions in multi-elements solutions of low and high metal ion concentration is shown in Figure 2.

Although the trend was similar to that in the element solutions, the modified PTE resins performed poorly and demonstrated little competencies in removing the metal ions in the multi-elements solution. The metal ions competed with one another in the multi-elements solution during the adsorption process. Whereas 84.4 and 48.6; 79.8 and 46.7; 83.1 and 48.6; 71.7 and 41.1 and 81.8 and 51.8 percentages of $\mathrm{Fe}^{2+}$ respectively were bound by Crosslinked-PPTE, 


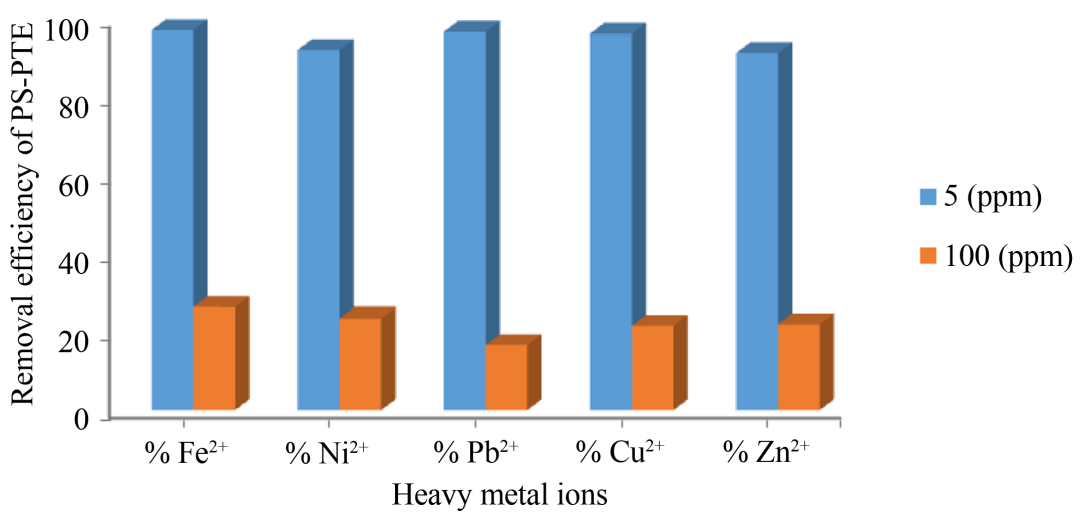

Figure 2. Comparison of $\%$ removal of $\mathrm{Fe}^{2+}, \mathrm{Ni}^{2+}, \mathrm{Pb}^{2+}, \mathrm{Cu}^{2+}$ and $\mathrm{Zn}^{2+}$ by PS-PTE in multi-elements solutions of low and high metal ions concentrations.

Table 5. Percent removal of $\mathrm{Fe}^{2+}, \mathrm{Ni}^{2+}, \mathrm{Pb}^{2+}, \mathrm{Cu}^{2+}$ and $\mathrm{Zn}^{2+}$ by modified-PTE resins and Bio-Rex 70 in a multi-elements Solution.

\begin{tabular}{cccccc}
\hline Resin Identity & $\% \mathrm{Fe}^{2+}$ & $\% \mathrm{Ni}^{2+}$ & $\% \mathrm{~Pb}^{2+}$ & $\% \mathrm{Cu}^{2+}$ & $\% \mathrm{Zn}^{2+}$ \\
\hline Crosslinked-PPTE & 48.60 & 49.30 & 45.60 & 41.60 & 33.80 \\
Substituted-PPTE & 46.70 & 41.60 & 39.80 & 41.20 & 38.30 \\
PS-PTE & 48.60 & 53.70 & 48.40 & 49.80 & 45.80 \\
SU-PTE & 41.10 & 42.40 & 38.70 & 37.10 & 34.20 \\
Bio-Rex 70 & 51.80 & 57.20 & 42.40 & 59.70 & 54.30 \\
\hline
\end{tabular}

Substituted-PPTE, PS-PTE, SU-PTE and Bio-Rex 70 in individual and multi-elements solutions, 97.2 and 26.3; 92.4 and 23.5; 96.8 and 16.6; 96.3 and 21.7 and 91.6 and $22.1 \%$ of the same were removed by PS-PTE in competitive environments of low and high metal ions concentration.

The results showed that the modified PTE resins demonstrated near equal capacities in removing the metal ions in the multi-elements solution. The effect of the competitive environment which showed to be relatively mild on $\mathrm{Fe}^{2+}$ significantly impacted $\mathrm{Zn}^{2+}$ which demonstrated the least adsorption on the resins. The variance between the amounts of a metal ion taken up by an adsorbent in the individual element solution and that in the multi-elements type can be attributed to reduction in the numeral of binding sites on the adsorbent which are available for occupation to the metal ion at the prevailing experimental conditions due to competition for the same sites with complementary ions present in the multi-elements solution. The number of sites available for occupation decreased due to overcrowding and blocking of adsorbent sites by the stampeding metal ions. Reference [36] [37] reported comparatively lower adsorption capacities for metal ion adsorbents and drastic reductions in the amounts of $\mathrm{Cu}, \mathrm{Zn}$ and $\mathrm{Pb}$ adsorbed from a ternary mixture by $\mathrm{HNO}_{3}$ treated oil palm root in contrast to the amounts of the metal ions removed from individual element solutions using the same adsorbent. Report [38] established the governance of the occupation of the limited 
binding sites on banana pith by equilibrium competitions between contending metal ions in the adsorbent-adsorbate mixture. The adsorption sites on the surfaces of the modified PTE resins in this study were contested for, occupied and saturated by metal ions with superior propensity against the susceptible ones. Consequently, adsorption sites partitioned and metal ions with greater and more favourable tenacity in terms of smaller ionic radii diffused freely and occupied the sites faster and more readily than the disadvantaged ones.

Whereas most of the metal ions in the multi-elements solution that contained $5 \mathrm{ppm}$ of the individual metal ions were absorbed by PS-PTE, the amounts of the same metal ions removed from that containing $100 \mathrm{ppm}$ of the ions were much reduced. This is as a result of the availability of adsorption sites for occupation to the metal ions in the multi-elements solution of low metal ions concentration, which relatively, was a dilute solution while the metals ions in the solution of high metal ions concentration, reasonably, a concentrated solution scrambled for few available sites. Competition was therefore less severe in the multi-elements solution of low metal ions concentration and vice-versa. This implies that the modified PTE adsorbents in this study would perform better and remove larger amounts of pollutant metal ions in wastewater if the concentrations of the metal ions are not so high.

\subsection{Cation Exchange Capacity of PT, PTE, PTE Cation Exchange Resins and Bio-Rex 70}

Ion exchange capacity (IEC) describes the ability of an insoluble polymeric material in a solution to replace flexible ionic charges in its structure with ions of opposite charge in the same solution with it. It is a crucial feature of all ion exchange resins; cationic or anionic alike and is expressed in terms of equivalents per litre in a liquid resin or milli-equivalents per gram in a dry powder. The CEC of a substance/polymeric material expresses its ability to exchange loosely bound positive ions in its structure with others in the same environment with it and is a pointer to the number of electrical charges of opposite sign on the material's surface. Other reports [26] equated its magnitude to the amount of polar functional groups integrated to the chemical structure of a biological polymer in a modification process. Another report [39] expressed it as the equivalence to the number of $\mathrm{H}^{+}$released by a cation exchange resin flooded by a solution of a neutral salt. CEC of the PTE resins in this study was estimated by exchanging $\mathrm{Na}^{+}$for $\mathrm{H}^{+}$(liberated during $\mathrm{HNO}_{3}$ activation or conversion of the resins to the $\mathrm{H}^{+}$forms) as a solution of $\mathrm{Na}_{2} \mathrm{SO}_{4}$ streamed through the resin and ranged between 4.23 and $9.52 \mathrm{meq} / \mathrm{g}$ [25]. This implies that Crosslinked-PPTE, Substituted-PPTE, PS-PTE and SU-PTE possessed higher CECs and accordingly higher numbers of replaceable $\mathrm{H}^{+}$than the starting materials.

\subsection{Point of Zero Charge $\left(\mathrm{pH}_{(\mathrm{pzc})}\right)$ of PT, PTE and PTE Resins}

Point of zero charge at different $\mathrm{pH}$ was determined for the individual resins in order to understand the surface properties of the PT adsorbents, hence, $\mathrm{pH}$ at 
zero point charge $\left(\mathrm{pH}_{(\mathrm{zpc})}\right)$. The $\mathrm{pH}_{(\mathrm{ZPC})}$ of an adsorbent is an essential property that communicates the $\mathrm{pH}$ at which there are no electrical charges on its surface. Defined as the point, on the $\mathrm{pH}$ scale at which the properties of the adsorbent-adsorbate suspension is unaffected by the surface characteristics (acidic or basic) of the adsorbent, it is the point on the graph where the arc of the plot of the variance between the initial and final $\mathrm{pH}\left(\Delta \mathrm{pH}=\mathrm{pH}_{\mathrm{i}}-\mathrm{pH}_{\mathrm{f}}\right)$ of the suspension against the initial $\mathrm{pH}$ i.e. $\Delta \mathrm{pH}$ verses $\mathrm{pH}_{\mathrm{i}}$ intersect and corresponds to $\mathrm{pH}_{\mathrm{i}}-$ $\mathrm{pH}_{\mathrm{f}}$ t thus, $\Delta \mathrm{pH}=\mathrm{pH}_{\mathrm{i}}-\mathrm{pH}_{\mathrm{f}}=0$. The $\mathrm{pH}_{(\mathrm{zpc})}$ of PT, PTE, Crosslinked-PPTE and Substituted-PPTE as well as PS-PTE and SU-PTE reported [25] are all less than the $\mathrm{pH}$ of the adsorbate solution ( $\mathrm{pH}=6 \pm 0.5$ ), which explains their ability to remove metal ions in an aqueous solution. Since an adsorbent's surface characteristically saturates with groups of comparable, rather than complementary $\mathrm{pH}$, Crosslinked-PPTE, Substituted-PPTE, PS-PTE and SU-PTE possess the capacity to operate over a wide $\mathrm{pH}$ range with individual resin surface hosting positive or negative charges respectively as the $\mathrm{pH}$ of the solution fluctuates below or above its $\mathrm{pH}_{(\mathrm{pzc})}$.

The functional groups $\left(-\mathrm{SO}_{3} \mathrm{H},-\mathrm{P}=\mathrm{O},-\mathrm{P}-\mathrm{OH},-\mathrm{C}-\mathrm{O}-\mathrm{S}\right.$ and $\left.\mathrm{O}=\mathrm{S}=\mathrm{O}\right)$ incorporated on $\mathrm{PTE}$ by the modification brought about a reduction in the $\mathrm{pH}_{(\mathrm{pzc})}$ of all the products. Individual resins, therefore, attracted the positively charged metal ions at a $\mathrm{pH}$ where negative charges converged at its surface. Metal ion adsorption capacity of an adsorbent improves by increased $\mathrm{pH}$ of the surrounding solution, the effect of which, the presence of negative charges on the adsorbent's surface is boosted. Reference [40] explained that maleic acid modified Babasuepicarp (BEM) readily attracted positive charges after the $\mathrm{pH}$ of the adsorbate solution surpassed the $\mathrm{pH}_{(\mathrm{pzc})}$ at 6.45 because the formation of negative chargeson the surface of BEM, which was essential for metal ion adsorption was only feasible at that $\mathrm{pH}$. As the magnitude of negative charges disproportionate between $\mathrm{pH}_{\mathrm{i}}$ and $\mathrm{pH}_{(\mathrm{pzc})}$ in favour of $\mathrm{pH}_{\mathrm{i}}$, all the modified $\mathrm{PTE}$ resins removed more metal ions in line with the size difference between its $\mathrm{pH}_{(\mathrm{pzc})}$ and $\mathrm{pH}$ of the solution at the commencement of the experiment. The increase in the amount of a metal ion removed climaxed at $\mathrm{pH} 8.0$ and thereafter diminished until equilibrium due to the formation of an adsorbent-metal complex that shielded the adsorbent surface and restricted interaction between the resin and the metal ion in the solution.

\section{Conclusion}

The use of peanut testa for wastewater purification demonstrated in this study illustrates gainful ways to transform this waste that has defaced the landscape in many cities into potential strong cation exchange resins.

\section{Acknowledgements}

The authors are grateful to the World Bank African Centre for Oilfield Chemicals Research for partially funding the research. Also, the Management and Staff 
of Getamme Laboratory Services, Port Harcourt for providing the facilities for the experiments and the Management and Staff of Idex Scientific Supplies Company for providing the chemicals.

\section{Conflicts of Interest}

The authors declare no conflicts of interest.

\section{References}

[1] Uchechukwu, T.O., Chukwu, U.J. and Akaranta, O. (2016) Removal of Heavy Metal Ions in Produced Water Using Cation Exchange Resins from Formaldehyde Polymerized Peanut Testa (Arachis hypogaea L.) Extract Catechins. IOSR Journal of Applied Chemistry, 9, 35-41.

[2] Darbari, D.S., Kple-Faget, P., Kwagyan, J., Rana, S., Gordeuk, V.R. and Castro, O. (2006) Circumstances of Death in Adult Sickle Cell Disease Patients. American Journal of Hematology, 81, 858-863. https://doi.org/10.1002/ajh.20685

[3] Abetz, L., Baladi, J.F., Jones, P. and Rofail, D. (2006) The Impact of Iron Overload and Its Treatment on Quality of Life: Results from a Literature Review. Health and Quality of Life Outcomes, 4, Article No. 73. https://doi.org/10.1186/1477-7525-4-73

[4] Duruibe, J.O., Ogwuegbu, M.O.C. and Egwurugwu, J.N. (2007) Heavy Metal Pollution and Human Biotoxic Effects. International Journal of Physical Sciences, 2, 112118.

[5] Lead Action News (2009) Iron Nutrition and Lead Toxicity. Lead, 9, 1-15.

[6] Shirkhanloo, H., Mirzahosseini, S.A.H., Shirkhanloo, N., Moussavi-Najarkola, S.A. and Farahani, H. (2015) The Evaluation and Determination of Heavy Metals Pollution in Edible Vegetables, Water and Soil in the South of Tehran Province by GIS. Archives of Environmental Protection, 41, 64-74. https://doi.org/10.1515/aep-2015-0020

[7] Sardar, K., Ali, S., Hameed, S., Afzal, S., Fatima, S., Shakoor, M.B., Bharwana, S.A. and Tauqeer, H.M. (2013) Heavy Metals Contamination and What Are the Impacts on Living Organisms. Greener Journal of Environmental Management and Public Safety, 2, 172-179.

[8] Igwe, C.O., Saadi, A.A. and Ngene, S.E. (2013) Optimal Options for Treatment of Produced Water in Offshore Petroleum Platforms. Journal of Pollution Effects and Control, 1, 1-5.

[9] Reis, L.S.L.S., Pardo, P.E., Camargos, A.S. and Oba, E. (2010) Mineral Element and Heavy Metal Poisoning in Animals. Journal of Medicine and Medical Sciences, 1, 560-579.

[10] Ogali, R.E., Akaranta, O. and Aririguzo, V.O. (2008) Removal of Some Metal Ions from Aqueous Solution Using Orange Mesocarp. African Journal of Biotechnology, 7, 3073-3076.

[11] UNEP/Earthprint and Hertwich, E. (2010) Assessing the Environmental Impacts of Consumption and Production: Priority Products and Materials.

[12] Corcoran, E. (2010) Sick Water: The Central Role of Wastewater Management in Sustainable Development: A Rapid Response Assessment. UNEP, Nairobi.

[13] Uchechukwu, T.O. (2017) Cation Exchange Properties of Chemically Modified Peanut (Arachis hypogaea L.) Testa Extract. Ph.D. Thesis, Department of Pure and Industrial Chemistry, University of Port Harcourt, Port Harcourt. 
[14] Igunnu, E.T. and Chen, G.Z. (2014) Produced Water Treatment Technologies. International Journal of Low-Carbon Technologies, 9, 157-177. https://doi.org/10.1093/ijlct/cts049

[15] Ezechi, E.H., Isa, M.H. and Kutty, S.R.B.M. (2012) Boron in Produced Water: Challenges and Improvements: A Comprehensive Review. Journal of Applied Sciences, 12, 402-415. https://doi.org/10.3923/jas.2012.402.415

[16] Tansel, B. (2008) New Technologies for Water and Wastewater Treatment: A Survey of Recent Patents. Recent Patents on Chemical Engineering, 1, 17-26. https://doi.org/10.2174/2211334710801010017

[17] Nada, A.M.A., Moussa, W.M., Abd El-Mongy, S. and Abd El-Sayed, E.S. (2009) Physicochemical Studies of Cation Ion Exchange Wood Pulp. Australian Journal of Basic and Applied Sciences, 3, 9-16.

[18] Yadav, D.N., Yogesh, K. and Aswani, A. (2014) Antioxidant Activity of Peanut (Arachis hypogaea L.) Skin Extract: Application in Soybean and Mustard Oil. Int. J. of Food Processing Technology, 1, 26-31. https://doi.org/10.15379/2408-9826.2014.01.02.5

[19] Zhang, H., Liu, M., Han, S. and Wei, Y. (2013) Optimizing the Extraction of Catechin from Peanut Red Skin Using Response Surface Methodology and Its Antioxidant Activity. IERI Procedia, 5, 312-320.

https://doi.org/10.1016/j.ieri.2013.11.109

[20] Levy, J., Boyer, R.R., Neilson, A.P., O’Keefe, S.F., Chu, H.S.S., Williams, R.C., et al. (2017) Evaluation of Peanut Skin and Grape Seed Extracts to Inhibit Growth of Food Borne Pathogens. Food Science \& Nutrition, 5, 1130-1138. https://doi.org/10.1002/fsn3.503

[21] Holser, R.A. (2014) Near-Infrared Analysis of Peanut Seed Skins for Catechins. American Journal of Analytical Chemistry, 5, 378-383.

https://doi.org/10.4236/ajac.2014.56046

[22] Hathorn, C.S. and Sanders, T.H. (2012) Flavor and Antioxidant Capacity of Peanut Paste and Peanut Butter Supplemented with Peanut Skins. Journal of Food Science, 77, S407-S411. https://doi.org/10.1111/j.1750-3841.2012.02953.x

[23] Zhao, X., Chen, J. and Du, F. (2012) Potential Use of Peanut By-Products in Food Processing: A Review. Journal of Food Science and Technology, 49, 521-529.

[24] Sobolev, V.S. and Cole, R. J. (2004) Note on Utilisation of Peanut Seed Testa. Journal of the Science of Food and Agriculture, 84, 105-111. https://doi.org/10.1002/jsfa.1593

[25] Chukwu, U.J., Uchechukwu, T.O. and Akaranta, O. (2018) Synthesis of New Cation Exchanger Resins from Chemically Modified Peanut (Arachis hypogaea L.) Testa Extract. Journal of American Science, 14, 69-75.

[26] Anggraeni, A., Hadiman, R., Agma, M. and Bahti, H.H. (2008) Preparation of Phosphoric-Cation Exchanger from Banana Stem Cellulose Fibre. Proceeding of the International Seminar on Chemistry, Jatinangor, 30-31 October 2008, 85-88.

[27] Eid, M.A., Mahdy, A.A., Eid, K.A., Hashem, H.A. and Nada, A.M.A. (2007) Behaviour of Chemically Modified Bagasse in Sorption of Rare Earth Elements. Journal of Scientific and Industrial Research, 66, 162-169.

[28] Coates, J. (2006) Interpretation of Infrared Spectra, a Practical Approach. In: Meyers, R.A., Ed., Encyclopedia of Analytical Chemistry: Applications, Theory and Instrumentation, John Wiley and Sons Ltd., Chichester, 10815-10837.

https://doi.org/10.1002/9780470027318.a5606 
[29] Mohandas, J., Kumar, T., Rajan, S.K., Velmurugan, S. and Narasimhan, S.V. (2008) Introduction of Bifunctionality into the Phosphinic Acid Ion-Exchange Resin for Enhancing Metal Ion Complexation. Desalination, 232, 3-10. https://doi.org/10.1016/j.desal.2008.01.005

[30] Alexandratos, S.D. and Natesan, S. (1999) Ion-Selective Polymer-Supported Reagents: The Principle of Bifunctionality. European Polymer Journal, 35, 431-436. https://doi.org/10.1016/S0014-3057(98)00142-6

[31] Beauvais, R.A. and Alexandratos, S.D. (1998) Polymer-Supported Reagents for the Selective Complexation of Metal Ions: An Overview. Reactive and Functional Polymers, 36, 113-123. https://doi.org/10.1016/S1381-5148(98)00016-9

[32] Abdel-Kader, A.H. (2012) Preparation of Lignin from Waste Black Liquors as Ion Exchangers. Der Chemica Sinica, 3, 689-697.

[33] Horsfall, M.J., Arbia, A.A. and Spiff, A.I. (2003) Removal of Cu (II) and Zn (II) Ions from Wastewater by Cassava (Manihot Esculenta Cranz) Waste Biomass. African Journal of Biotechnology, 2, 360-364. https://doi.org/10.5897/AJB2003.000-1074

[34] Patil A., Hatch, G., Michaud, C., et al. (2013) Ion Exchange. WQA Technical Fact Sheet, Water Quality Association. https://www.wqa.org/

[35] Nada, A.M.A., El-Gendy, A.A. and Mohamed, S.H. (2010) Banana Leaves as Adsorbents for Removal of Metal Ions from Waste Water. Carbohydrate Polymers, 82, 1025-1030. https://doi.org/10.1016/j.carbpol.2010.03.004

[36] Bhat, I.U.H., Mungkar, A.N., Lee, K.E. and Khanam, Z. (2014) Oil Palm Root as Biosorbent for Heavy Metals: Biosorption, Desorption and Isothermal Studies. International Journal of Chem Tech Research, 6, 163-177.

[37] Şengil, İ.A. and Özacar, M. (2009) Competitive Biosorption of $\mathrm{Pb}^{2+}, \mathrm{Cu}^{2+}$ and $\mathrm{Zn}^{2+}$ Ions from Aqueous Solutions onto Valonia Tannin Resin. Journal of Hazardous Materials, 166, 1488-1494. https://doi.org/10.1016/j.jhazmat.2008.12.071

[38] Low, K.S., Lee, C.K. and Leo, A.C. (1995) Removal of Metals from Electroplating Wastes Using Banana Pith. Bioresource Technology, 51, 227-231. https://doi.org/10.1016/0960-8524(94)00123-I

[39] Singh, A.V. and Kumawat, I.K. (2012) Preparation and Characterisation of Tamarind 4-Hydroxybenzoic Acid (THBA) Resin and Its Use in Extraction of Heavy Metal Ions from Industrial Wastewater. Water $S A$, 38, 529-536. https://doi.org/10.4314/wsa.v38i4.7

[40] Vieira, A.P., Santana, S.A.A., Bezerra, C.W.B., Silva, H.A.S., Santos, K.C.A., Melo, J.C.P., Silva Filho, E.C. and Airoldi, C. (2014) High Performance Maleated Lignocellulose Epicarp Fibers for Copper Ion Removal. Brazilian Journal of Chemical Engineering, 31, 183-193. https://doi.org/10.1590/S0104-66322014000100017 